\title{
Correlation of the oldest Toba Tuff to sediments in the central Indian Ocean Basin
}

\author{
J N Pattan ${ }^{1, *}$, M Shyam Prasad ${ }^{1, * *}$ and E V S S K Babu ${ }^{2, \dagger}$ \\ ${ }^{1}$ National Institute of Oceanography (CSIR), Dona Paula, Goa 403 004, India. \\ ${ }^{2}$ National Geophysical Research Institute (CSIR), Uppal Road, Hyderabad 500 00\%, India. \\ *e-mail: pattan@nio.org \\ **e-mail: shyam@nio.org \\ †e-mail: evsskbabu@yahoo.co.in
}

We have identified an ash layer in association with Australasian microtektites of $\sim 0.77 \mathrm{Ma}$ old in two sediment cores which are $\sim 450 \mathrm{~km}$ apart in the central Indian Ocean Basin (CIOB). Morphology and chemical composition of glass shards and associated microtektites have been used to trace their provenance. In ODP site 758 from Ninetyeast Ridge, ash layer-D $(13 \mathrm{~cm}$ thick, $0.73-0.75 \mathrm{Ma})$ and layer-E (5 cm thick, $0.77-0.78 \mathrm{Ma})$ were previously correlated to the oldest Toba Tuff (OTT) eruptions of the Toba caldera, Sumatra. In this investigation, we found tephra $\sim 3100 \mathrm{~km}$ to the southwest of Toba caldera that is chemically identical to layer D of ODP site 758 and ash in the South China Sea correlated to the OTT. Layer E is not present in the CIOB or other ocean basins. The occurrence of tephra correlating to layer D suggests a widespread distribution of OTT tephra $\left(\sim 3.6 \times 10^{7} \mathrm{~km}^{2}\right)$, an ash volume of at least $\sim 1800 \mathrm{~km}^{3}$, a total OTT volume of $2300 \mathrm{~km}^{3}$, and classification of the OTT eruption as a super-eruption.

\section{Introduction}

The $\sim 74$ ka YTT eruption from northern Sumatra represents one of the largest explosive eruptions of the Quaternary period, discharging between 2500 and $3000 \mathrm{~km}^{3}$ of magma (Rose and Chesner 1987). Its occurrence is well documented in parts of the Bay of Bengal (Ninkovich et al 1979; Dehn et al 1991), central Indian Ocean Basin (Pattan et al 1999), western continental margin of India (Pattan et al 2001; Nambiar and Sukumaran 2002) Murray Ridge (Schulz et al 2002), Indian subcontinent (Korishetter et al 1989; Acharyya and Basu 1993; Shane et al 1995; Westgate et al 1998), and the South China Sea (Bühring et al 2000; Song et al 2000). The geographic distribution of YTT ash is suggestive of a wind direction that was NE to SW during the eruption time. The new occurrence of YTT to the northwest of India (Pattan et al 2001) further widens wind direction towards north. The
YTT occurred near the marine isotope stage 5-4 boundary (Bühring et al 2000; Schulz et al 2002) leading (Rampino and Self 1993) to suggest that global cooling was triggered by the YTT eruption. In addition to the YTT, Toba has also been the site of other large explosive eruptions in the past: the Haranggoal Dacite Tuff (HDT) having a zircon fission-track age of $1.2 \pm 0.16 \mathrm{Ma}$ (Nishimura et al 1977), the oldest Toba Tuff (OTT) with a sanidine based ${ }^{40} \mathrm{Ar} \backslash{ }^{39} \mathrm{Ar}$ age of $0.84 \pm 0.3 \mathrm{Ma}$ (Diehl et al 1987) and the middle Toba Tuff (MTT) with an age of $0.501 \pm 0.005 \mathrm{Ma}$ based on $\left.{ }^{40} \mathrm{Ar}\right\rangle{ }^{39} \mathrm{Ar}$ of sanidine phenocrysts (Diehl et al 1987; Chesner and Rose 1991). The repose periods between the four Toba Tuffs range between 0.34 Ma and 0.42 Ma with an average of $0.37 \mathrm{Ma}$. The occurrence of YTT, MTT, OTT and HDT layers have been tentatively correlated with layers A, C, E and F respectively at ODP site 758 that was based on paleomagnetic and $\delta^{18} \mathrm{O}$ data (Dehn et al 1991).

Keywords. Central Indian Ocean Basin; ash layer; Australasian microtektite; layer D; oldest Toba Tuff; new volume estimates. 


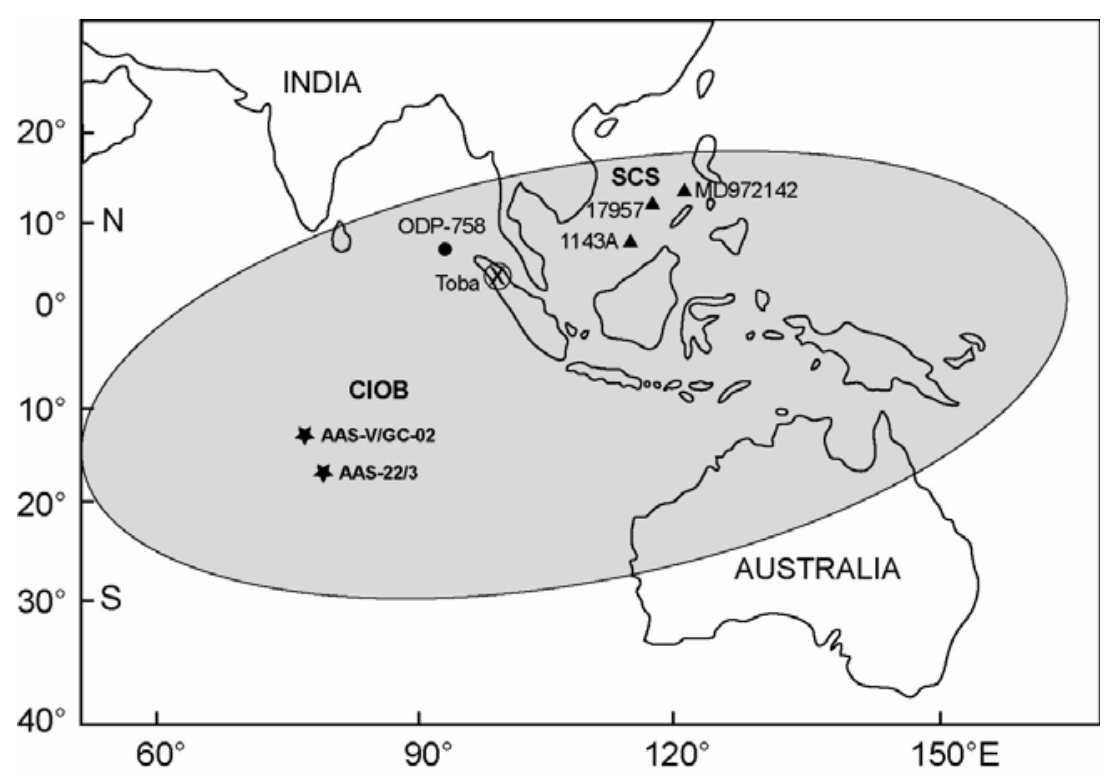

Figure 1. Map showing location of sediment cores (AAS-V/GC-02; AAS-22/3) from CIOB, South China Sea (MD972142, 17957, 1143A), ODP site 758 and Toba caldera. The shaded area was proposed by Glass and Koeberl (2006) based on the co-occurrence of Australasian microtektites and ash layers of OTT origin

At ODP site 758 , layer D occurs at a depth of $10.80 \mathrm{~m}$ to $10.93 \mathrm{~m}$ ( $13 \mathrm{~cm}$ thick) below the sea floor corresponding to an age of $0.731-0.750 \mathrm{Ma}$ whereas, layer E occurs at 11.62 to $11.67 \mathrm{~m}(5 \mathrm{~cm}$ thick) depth below the seafloor with an age ranging from 0.774 to $0.780 \mathrm{Ma}$ (Dehn et al 1991). The OTT erupted from the southern part of Toba and is mostly densely welded and rests on marine sediments of Paleozoic and Mesozoic age (Knight et al 1986). Whole rock analysis of OTT from Toba indicates a rhyolitic composition (Chesner and Rose 1991). Lee et al (2004) suggested that the ash layer occurring just above the microtektites in the South China Sea (SCS) correlates chemically very well with layer D from ODP site 758 and is likely OTT. On the contrary, an ash layer above the microtektite layer in both the Pacific and central Indian Oceans matches neither layer D nor E (Glass and Koeberl 2006). Furthermore, it is still not clear as to whether the OTT correlates with tephra layer D or E (which are two closely-spaced events) reported from ODP site 758 in the Ninetyeast Ridge (Dehn et al 1991). Therefore, in the present investigation of two CIOB sediment cores, we describe the composition of ash and microtektite layers in an effort to identify their sources.

\section{Materials and methods}

A $5 \mathrm{~m}$ long sediment core from a siliceous ooze domain in the northern part of the CIOB $\left(13^{\circ} 03^{\prime} \mathrm{S}\right.$ : $75^{\circ} .451 \mathrm{E}$, water depth of $5099 \mathrm{~m}$ ) was retrieved onboard A A Sidorenko cruise V (AAS-V/GC-02) during August-September 1994. A second core of $5.6 \mathrm{~m}$ long from a red clay area in the southern part of CIOB $\left(17^{\circ} 00 \mathrm{~S}\right.$ : $78^{\circ} .00 \mathrm{E}$, water depth $\left.4760 \mathrm{~m}\right)$ was retrieved onboard A A Sidorenko cruise 22 (AAS-22/3) during October-November 1999. The distance between these two sediment cores is about $450 \mathrm{~km}$ (figure 1). Sediment core AAS-V/GC-02 was sub-sampled at $2 \mathrm{~cm}$ continuous intervals in the top $1 \mathrm{~m}$ and the remaining $4 \mathrm{~m}$ at $5 \mathrm{~cm}$ intervals; whereas core AAS-22/3 was sub-sampled at $5 \mathrm{~cm}$ intervals throughout. Coarse fractions $(>63 \mu \mathrm{m})$ of sediment samples were obtained by wet sieving. Glass shards and microtektites were searched for using a binocular microscope. The $>63 \mu \mathrm{m}$ coarse fraction was sieved again for $>125 \mu \mathrm{m}$ and from this fraction microtektite abundance was calculated. Glass shards from the coarse fraction were separated using bromoform liquid, then washed with water and cleaned ultrasonically. The method followed in isolating the microtektites is described by Prasad et al (2007). Morphology of microtektites and glass shards was observed using a JEOL JSM-5800LV Scanning Electron Microscope at the National Institute of Oceanography, Goa. Major element composition of microtektites and glass shards from sediment core AAS-V/GC-02 were determined using a Cameca SX 100 Electron Microprobe Analyser at the National Geophysical Research Institute, Hyderabad. The operating conditions were $20 \mathrm{kV}$ accelerating voltage, $5 \mu \mathrm{m}$ beam diameter and $20 \mathrm{nA}$ beam current. Tektite standard USNM 2213 made by Corning Glass Company and analysed by USGS (Jarosewich et al 1980) was used and 


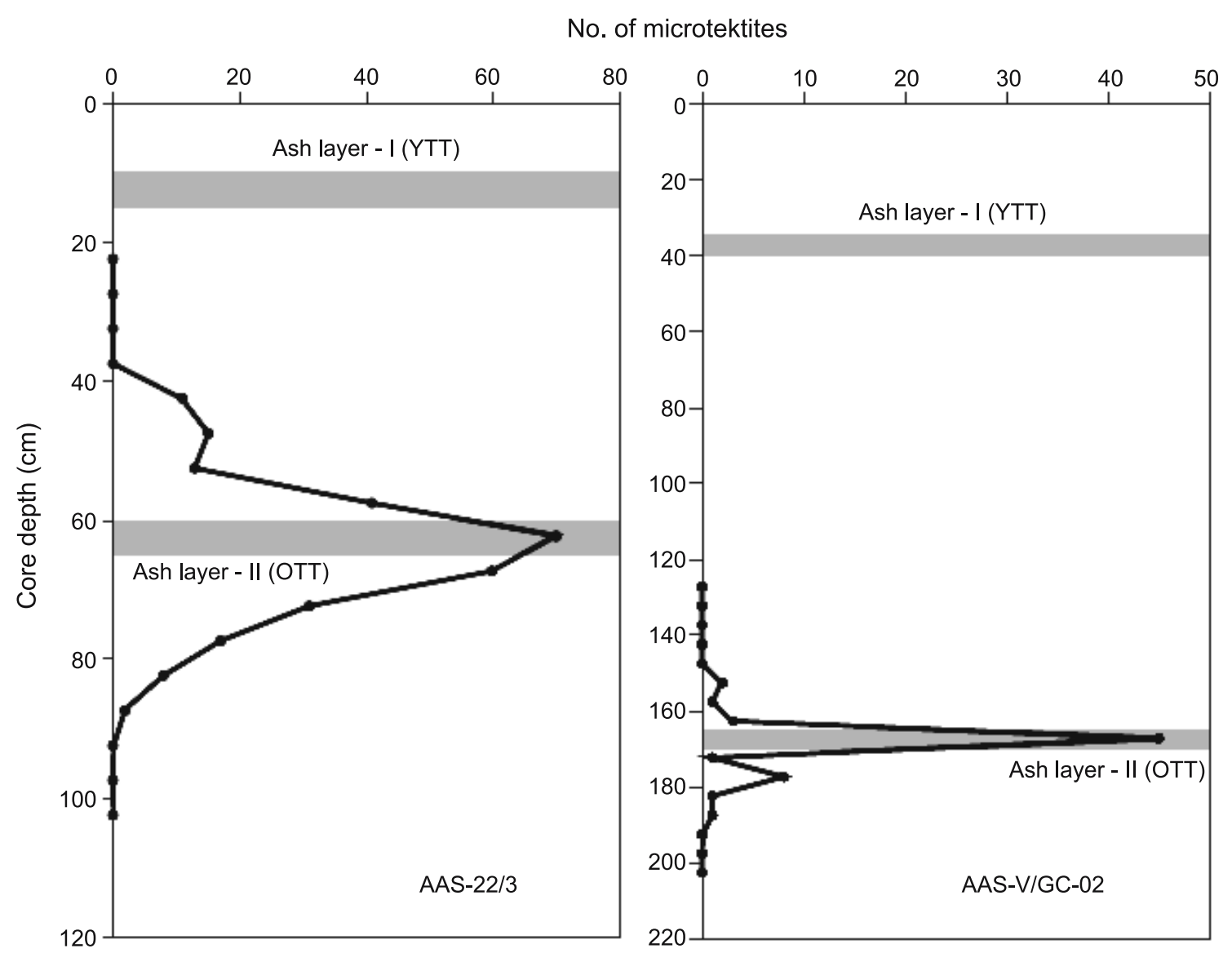

Figure 2. Occurrence of first ash layer in the core top as YTT and second ash layer (OTT) in association with Australasian microtektites in two sediment cores from CIOB. Ash layers are based on relative abundance of glass shards in coarse fraction rather than actual counts. Bold line is microtektite abundance.

the accuracy of the data was better than $\pm 0.4 \%$. Both synthetic and natural standards supplied by $\mathrm{M} / \mathrm{s}$ MAC analytical consultants; U.K. and M/s Cameca, France were used for the calibration. Online computer was used for ZAF corrections. Repeated analysis of in-house standards prepared from Mid Oceanic Ridge Basalts glass were used to monitor the quality of analysis. To improve the quality of some low abundance elements ( $\mathrm{Ti}$ and $\mathrm{Mn}$ ), analytical strategy of integrating data from the analysis on more than one spectrometer was used. This resulted $<0.5 \%$ error on major elements. Major element composition of glass shards from sediment core AAS-22/3 were analysed at the University of Auckland using a Jeol JXA-5A electron microprobe fitted with a Link Systems LZ-5 EDS detector using as absorbed current of $0.5 \mathrm{nA}$ at $15 \mathrm{kV}$, and a beam defocused to $15 \mu \mathrm{m}$.

\section{Results and discussion}

The uppermost ash layer in sediment cores of AAS-V $/$ GC-02 and AAS- $22 / 3$ occurs at $36-40 \mathrm{~cm}$ and $10-15 \mathrm{~cm}$ core depths whereas the second ash layer containing microtektites occurs at $165-170 \mathrm{~cm}$ and $60-65 \mathrm{~cm}$ depth respectively (figure 2). Ash layers in these sediment cores are based on the relative abundance of glass shard contents in their coarse fractions rather than actual shard counts. The chemical composition of the first ash layer in the entire CIOB correlates well with that of YTT (Pattan et al 1999, 2003). Electron microprobe data of microtektites and glass shards from the second ash layers and a comparison with other locations are presented in tables 1 and 2. Microtektites exhibit large variation in total $\mathrm{SiO}_{2} \quad$ (63.51-71.41 wt\%), $\mathrm{MgO} \quad(3.18-8.32 \mathrm{wt} \%)$ and $\mathrm{MnO}(0.08-0.17 \mathrm{wt} \%)$ whereas $\mathrm{TiO}_{2}$ and $\mathrm{FeO}$ contents are almost constant (table 1 ). Second ash layers have mean high silica (77.33 wt\%) and total alkalies (8.02 wt\%) with low concentrations of $\mathrm{MnO}$ (0.07 wt\%), $\mathrm{MgO}(0.07 \mathrm{wt} \%)$ and $\mathrm{TiO}_{2}(0.05 \mathrm{wt} \%)$ and moderate contents of $\mathrm{CaO}(0.77 \mathrm{wt} \%)$ and $\mathrm{FeO}$ $(0.86 \mathrm{wt} \%)$ (table 2).

The $5 \mathrm{~cm}$ thick peak of microtektite abundance (number of microtektites of $>125 \mu \mathrm{m} / \mathrm{cm}^{2}$ ) is associated with the highest abundance of glass shards from the older ash layers in both the sediment cores (figure 2) and their occurrence 
Table 1. Chemical composition (wt\%) of microtektites (EPMA, average of three spot analyses) from CIOB sediment cores (AAS-22/3 and AAS-V/GC-02) and Australasian microtektite fields (C, D and E).

\begin{tabular}{|c|c|c|c|c|c|c|c|c|c|c|}
\hline Sample code & $\mathrm{SiO}_{2}$ & $\mathrm{TiO}_{2}$ & $\mathrm{Al}_{2} \mathrm{O}_{3}$ & $\mathrm{FeO}$ & $\mathrm{MnO}$ & $\mathrm{MgO}$ & $\mathrm{CaO}$ & $\mathrm{Na}_{2} \mathrm{O}$ & $\mathrm{K}_{2} \mathrm{O}$ & $\mathrm{Cr}_{2} \mathrm{O}_{3}$ \\
\hline \multicolumn{11}{|l|}{ AAS-V/GC-02 } \\
\hline TKT-01 & 67.31 & 0.88 & 14.28 & 5.93 & 0.14 & 6.08 & 3.19 & 0.72 & 1.41 & 0.07 \\
\hline TKT-02 & 63.51 & 0.96 & 16.71 & 5.38 & 0.10 & 8.32 & 4.17 & 0.33 & 0.46 & 0.06 \\
\hline TKT-03 & 66.02 & 0.90 & 15.94 & 6.12 & 0.17 & 5.61 & 3.32 & 0.72 & 1.19 & 0.02 \\
\hline TKT-04 & 68.67 & 0.80 & 14.97 & 6.16 & 0.08 & 3.85 & 3.06 & 0.68 & 1.73 & 0.02 \\
\hline TKT-05 & 71.41 & 0.78 & 13.75 & 5.05 & 0.17 & 3.18 & 2.75 & 0.77 & 2.11 & 0.03 \\
\hline TKT-06 & 70.12 & 0.90 & 14.63 & 5.14 & 0.12 & 3.31 & 3.04 & 0.73 & 2.00 & 0.01 \\
\hline $\begin{array}{l}\text { Mean } \\
\text { Std. dev. (A) }\end{array}$ & $\begin{array}{l}67.84 \\
(3.19)\end{array}$ & $\begin{array}{c}0.87 \\
(0.09)\end{array}$ & $\begin{array}{l}15.05 \\
(1.30)\end{array}$ & $\begin{array}{l}5.63 \\
(0.67)\end{array}$ & $\begin{array}{c}0.13 \\
(0.04)\end{array}$ & $\begin{array}{c}5.06 \\
(1.94)\end{array}$ & $\begin{array}{c}3.25 \\
(0.52)\end{array}$ & $\begin{array}{c}0.66 \\
(0.16)\end{array}$ & $\begin{array}{c}1.48 \\
(0.59)\end{array}$ & $\begin{array}{c}0.04 \\
(0.04)\end{array}$ \\
\hline $\begin{array}{l}\text { AAS- } 22 / 3 \\
\text { Avg. }(n=17)(\mathrm{B})-\#\end{array}$ & $\begin{array}{l}70.09 \\
(3.04)\end{array}$ & $\begin{array}{c}0.82 \\
(0.14)\end{array}$ & $\begin{array}{l}15.07 \\
(4.39)\end{array}$ & $\begin{array}{c}5.51 \\
(0.93)\end{array}$ & - & $\begin{array}{c}4.20 \\
(1.32)\end{array}$ & $\begin{array}{c}3.20 \\
(0.96)\end{array}$ & $\begin{array}{c}0.62 \\
(0.18)\end{array}$ & $\begin{array}{c}0.97 \\
(0.40)\end{array}$ & - \\
\hline $\begin{array}{l}\text { Mean of } \\
\text { Australasian } \\
\text { microtektite } \\
(n=30)(\mathrm{C})\end{array}$ & $\begin{array}{l}69.10 \\
(2.68)\end{array}$ & $\begin{array}{c}0.87 \\
(0.09)\end{array}$ & $\begin{array}{l}15.00 \\
(1.82)\end{array}$ & $\begin{array}{c}5.34 \\
(0.86)\end{array}$ & - & $\begin{array}{c}3.42 \\
(0.97)\end{array}$ & $\begin{array}{c}3.60 \\
(0.78)\end{array}$ & $\begin{array}{c}0.92 \\
(0.44)\end{array}$ & $\begin{array}{l}1.77 \\
(0.81)\end{array}$ & - \\
\hline $\begin{array}{l}\text { Range of } \\
\text { Australasian } \\
\text { microtektite } \\
(n=60)(\mathrm{D})\end{array}$ & $\begin{array}{l}49.6 \text { to } \\
77.0\end{array}$ & $\begin{array}{l}0.5 \text { to } \\
1.0\end{array}$ & $\begin{array}{l}7.5 \text { to } \\
22.1\end{array}$ & $\begin{array}{l}3.0 \text { to } \\
8.1\end{array}$ & - & $\begin{array}{l}1.9 \text { to } \\
17.1\end{array}$ & $\begin{array}{l}1.0 \text { to } \\
5.8\end{array}$ & $\begin{array}{l}0.2 \text { to } \\
2.8\end{array}$ & $\begin{array}{l}0.1 \text { to } \\
3.7\end{array}$ & - \\
\hline $\begin{array}{l}\text { Mean of } \\
\text { Australasian } \\
\text { microtektite (E) }\end{array}$ & $\begin{array}{l}67.20 \\
(4.0)\end{array}$ & $\begin{array}{c}0.78 \\
(0.08)\end{array}$ & $\begin{array}{l}15.60 \\
(2.6)\end{array}$ & $\begin{array}{c}5.91 \\
(0.68)\end{array}$ & $\begin{array}{c}0.05 \\
(0.02)\end{array}$ & $\begin{array}{c}3.07 \\
(0.48)\end{array}$ & $\begin{array}{c}2.88 \\
(0.89)\end{array}$ & $\begin{array}{c}1.61 \\
(0.45)\end{array}$ & $\begin{array}{c}2.90 \\
(0.74)\end{array}$ & $\begin{array}{c}0.05 \\
(0.02)\end{array}$ \\
\hline
\end{tabular}

Chemical data is recalculated to $100 \%$. Total Fe expressed as FeO. TKT-01 to 06 is analyses of microtektites from sediment core AAS-V/GC-02 at $165-170 \mathrm{~cm}$ depth. \# - Mean chemical data of microtektite $(n=17)$ from sediment core AAS-22/3 at 60-65 cm depth (Prasad et al 2003). Values in the brackets are standard deviation. $n$ is number of microtektites analysed. (A) - Core-AAS-V/GC-02, present study. (B) - Core-AAS-22/3, Prasad et al (2003). (C) - Glass et al (2004), (D) - Cassidy et al (1969). (E) - Glass and Koeberl (2006), - : data not available.

at different depths in each core reflect different sedimentation rates. The microtektites found in AAS-22/3 have been discussed earlier (Prasad et al 2003), those found in AAS-V/GC-02 are of similar morphology: about $95 \%$ of them are spherical; the others are oval, bun-shaped, discs, or dumbbell-shaped (Plate 1). The dominant colours of the microtektites are yellowish, yellowish-white or white; some of them are greenish to greenish yellow. The chemical composition of microtektites from AAS-22/3 was determined earlier (Prasad et al 2003) and the chemical compositions of six microtektites from AAS-V/GC-02 were determined for this study (table 1 ). Table 1 also shows the mean composition of Australasian microtektites (Glass et al 2004) and the chemical range of Australasian microtektites (Cassidy et al 1969). The average composition and the range of the compositions shown by the microtektites in both the cores (AAS-V/GC-02 and AAS-22/3) are within limits of that of the Australasian microtektites (table 1). This clearly suggests that microtektites in both sediment cores in the CIOB belong to the well dated Australasian tektite event of $\sim 0.77 \mathrm{Ma}$ (Izett and Obradovich 1992; Kunz et al 1995; Yamei et al 2000) and serves as a chronostratigraphic marker for the associated ash layer.
This strewn microtektite field encompasses most of the Indian Ocean, the southwestern Pacific Ocean and the landmasses of Indochina, Malaysia, Philippines and Australia. So far, Australasian microtektites have been found in 75 locations in the Indian and Pacific Oceans (Prasad et al 2007).

The morphology of volcanic glass shards is the diagnostic feature to identify the nature or type of magma. Glass shards from the ash layers are isotropic, appear to be fresh, without any cracks/fractures and alterations. The shard morphology consists of bubble-wall, Y-shaped, platy, and pumice shards implying an origin from an explosively erupted high silica magma (Plate 1).

The chemical composition of glass shards in both the sediment cores are identical suggesting a single source (table 2). All the glass shards are classified as high-silica rhyolites, $\mathrm{CaO}$ shows an inverse relation with $\mathrm{SiO}_{2}$ (figure 3) and characterized by low contents of $\mathrm{MnO}, \mathrm{MgO}$ and $\mathrm{TiO}_{2}$. Chemical composition of these glass shards correlates very well with layer D from ODP site 758 (Dehn et al 1991) and from the SCS (Lee et al 2004). In ODP site 758 , layers $\mathrm{D}$ and $\mathrm{E}$, with thicknesses of $13 \mathrm{~cm}$ and $5 \mathrm{~cm}$ respectively, occur very close to each other and both have been correlated to the OTT (Diehl et al 1987; Dehn et al 1991). Glass shards from 
Table 2. Chemical composition (wt\%) of glass shards (EPMA) from CIOB sediment cores (AAS-22/3 at 60-65 cm depth, and $A A S-V / G C-02$ at $165-170 \mathrm{~cm}$ depth) and compared with layer $D$ and $E$ from ODP site 758, SCS and from different locations.

\begin{tabular}{|c|c|c|c|c|c|c|c|c|c|c|c|c|}
\hline Sl. no. & $\mathrm{SiO}_{2}$ & $\mathrm{TiO}_{2}$ & $\mathrm{Al}_{2} \mathrm{O}_{3}$ & $\mathrm{FeO}$ & $\mathrm{MnO}$ & $\mathrm{MgO}$ & $\mathrm{CaO}$ & $\mathrm{Na}_{2} \mathrm{O}$ & $\mathrm{K}_{2} \mathrm{O}$ & $\mathrm{Cl}$ & $\mathrm{H}_{2} \mathrm{O}$ & $\begin{array}{l}\text { Total } \\
\text { oxides }\end{array}$ \\
\hline \multicolumn{13}{|l|}{$\mathrm{AAS}-22 / 3$} \\
\hline 1 & 76.61 & 0.02 & 12.57 & 0.81 & 0.13 & 0.02 & 0.83 & 3.43 & 5.38 & 0.20 & 5.80 & 94.20 \\
\hline 2 & 76.32 & 0.09 & 12.61 & 0.78 & 0.08 & 0.27 & 0.85 & 3.51 & 5.24 & 0.22 & 5.19 & 94.81 \\
\hline 3 & 77.22 & 0.06 & 12.20 & 0.81 & 0.01 & 0.06 & 0.75 & 3.67 & 5.05 & 0.17 & 5.68 & 94.32 \\
\hline 4 & 76.68 & 0.03 & 12.52 & 0.81 & 0.15 & 0.03 & 0.85 & 3.60 & 5.12 & 0.21 & 5.38 & 94.62 \\
\hline 5 & 76.92 & 0.30 & 12.53 & 0.85 & 0.06 & 0.06 & 0.74 & 3.57 & 5.04 & 0.13 & 6.89 & 93.11 \\
\hline 6 & 76.93 & 0.03 & 12.20 & 0.93 & 0.10 & 0.10 & 0.79 & 3.60 & 5.06 & 0.27 & 5.74 & 94.26 \\
\hline 7 & 77.13 & 0.01 & 12.37 & 0.69 & 0.14 & 0.10 & 0.71 & 3.44 & 5.17 & 0.24 & 5.60 & 94.40 \\
\hline 8 & 76.68 & bdl & 12.43 & 0.84 & 0.10 & 0.18 & 0.80 & 3.62 & 5.16 & 0.19 & 4.66 & 95.34 \\
\hline 9 & 76.45 & 0.16 & 12.61 & 0.99 & 0.04 & 0.05 & 0.85 & 3.58 & 5.05 & 0.21 & 4.84 & 95.16 \\
\hline $\begin{array}{l}\text { Mean } \\
\text { Std. dev. }\end{array}$ & $\begin{array}{l}76.77 \\
(0.30)\end{array}$ & $\begin{array}{c}0.05 \\
(0.05)\end{array}$ & $\begin{array}{l}12.45 \\
(0.16)\end{array}$ & $\begin{array}{c}0.83 \\
(0.09)\end{array}$ & $\begin{array}{c}0.09 \\
(0.05)\end{array}$ & $\begin{array}{c}0.10 \\
(0.08)\end{array}$ & $\begin{array}{c}0.80 \\
(0.05)\end{array}$ & $\begin{array}{c}3.56 \\
(0.08)\end{array}$ & $\begin{array}{l}5.14 \\
(0.11)\end{array}$ & $\begin{array}{c}0.20 \\
(0.04)\end{array}$ & $\begin{array}{c}5.53 \\
(0.65)\end{array}$ & 94.47 \\
\hline $\begin{array}{l}\text { AAS-V/GC-02 } \\
1\end{array}$ & 77.94 & 0.04 & 12.97 & 0.86 & 0.04 & 0.02 & 0.76 & 2.00 & 5.33 & $\mathrm{Nd}$ & 4.40 & 95.60 \\
\hline 2 & 77.16 & 0.05 & 13.32 & 0.87 & 0.06 & 0.06 & 0.76 & 2.38 & 5.31 & $\mathrm{Nd}$ & 5.04 & 94.96 \\
\hline 3 & 77.65 & 0.03 & 13.08 & 0.95 & 0.08 & 0.04 & 0.75 & 2.15 & 5.25 & $\mathrm{Nd}$ & 4.16 & 95.84 \\
\hline 4 & 77.93 & 0.05 & 12.84 & 0.88 & 0.06 & 0.04 & 0.74 & 2.16 & 5.24 & $\mathrm{Nd}$ & 4.27 & 95.73 \\
\hline 5 & 77.62 & 0.10 & 12.89 & 0.92 & 0.10 & 0.05 & 0.72 & 2.31 & 5.29 & $\mathrm{Nd}$ & 3.44 & 96.56 \\
\hline 6 & 77.86 & 0.04 & 12.89 & 0.86 & 0.08 & 0.04 & 0.77 & 2.29 & 5.15 & $\mathrm{Nd}$ & 3.59 & 96.41 \\
\hline 7 & 78.22 & 0.04 & 12.78 & 0.89 & 0.06 & 0.03 & 0.71 & 2.18 & 5.06 & $\mathrm{Nd}$ & 4.46 & 95.54 \\
\hline 8 & 77.55 & 0.01 & 13.04 & 0.84 & 0.04 & 0.06 & 0.76 & 2.31 & 5.32 & $\mathrm{Nd}$ & 4.60 & 95.40 \\
\hline 9 & 78.31 & 0.06 & 12.73 & 0.86 & 0.06 & 0.06 & 0.75 & 2.05 & 5.09 & $\mathrm{Nd}$ & 3.91 & 96.09 \\
\hline 10 & 78.17 & 0.03 & 12.80 & 0.96 & 0.03 & 0.05 & 0.79 & 2.07 & 5.08 & $\mathrm{Nd}$ & 3.67 & 96.33 \\
\hline $\begin{array}{l}\text { Mean } \\
\text { Std. dev. }\end{array}$ & $\begin{array}{l}77.84 \\
(0.35)\end{array}$ & $\begin{array}{c}0.05 \\
(0.02)\end{array}$ & $\begin{array}{l}12.93 \\
(0.17)\end{array}$ & $\begin{array}{c}0.89 \\
(0.04)\end{array}$ & $\begin{array}{c}0.06 \\
(0.02)\end{array}$ & $\begin{array}{c}0.05 \\
(0.01)\end{array}$ & $\begin{array}{c}0.75 \\
(0.02)\end{array}$ & $\begin{array}{c}2.19 \\
(0.13)\end{array}$ & $\begin{array}{l}5.21 \\
(0.11)\end{array}$ & $\mathrm{Nd}$ & $\begin{array}{l}4.15 \\
(0.50)\end{array}$ & 95.85 \\
\hline $\begin{array}{l}\text { CIOB } \\
n=19 \text { (A) }\end{array}$ & $\begin{array}{l}77.33 \\
(0.64)\end{array}$ & $\begin{array}{c}0.05 \\
(0.05)\end{array}$ & $\begin{array}{l}12.70 \\
(0.03)\end{array}$ & $\begin{array}{c}0.86 \\
(0.07)\end{array}$ & $\begin{array}{c}0.07 \\
(0.04)\end{array}$ & $\begin{array}{c}0.07 \\
(0.06)\end{array}$ & $\begin{array}{c}0.77 \\
(0.05)\end{array}$ & $\begin{array}{c}2.84 \\
(0.71)\end{array}$ & $\begin{array}{l}5.18 \\
(0.11)\end{array}$ & $\begin{array}{c}0.20 \\
(0.04)\end{array}$ & 4.76 & 95.24 \\
\hline $\begin{array}{l}\text { ODP- } 758, \\
\text { Layer D, } \\
n=13(\mathrm{~B})\end{array}$ & 77.75 & 0.07 & 12.38 & 0.87 & - & 0.02 & 0.79 & 2.92 & 5.19 & $\mathrm{Nd}$ & - & - \\
\hline $\begin{array}{l}\text { ODP-758, } \\
\text { Layer E, } \\
n=11(\mathrm{~B})\end{array}$ & 76.19 & 0.14 & 13.21 & 1.21 & - & 0.12 & 0.92 & 3.96 & 4.22 & $\mathrm{Nd}$ & - & - \\
\hline $\begin{array}{l}\text { South } \\
\text { China Sea } \\
n=50(\mathrm{C})\end{array}$ & 77.82 & 0.05 & 12.57 & 0.86 & 0.05 & 0.12 & 0.71 & 2.94 & 5.00 & $\mathrm{Nd}$ & - & - \\
\hline $\begin{array}{l}\text { Avg. from } \\
\text { diff. locations, } \\
n=42 \text { (D) }\end{array}$ & $\begin{array}{l}77.85 \\
(0.50)\end{array}$ & $\begin{array}{c}0.17 \\
(0.07)\end{array}$ & $\begin{array}{l}13.81 \\
(0.27)\end{array}$ & $\begin{array}{c}0.72 \\
(0.15)\end{array}$ & $\begin{array}{c}0.18 \\
(0.08)\end{array}$ & $\begin{array}{c}0.18 \\
(0.14)\end{array}$ & $\begin{array}{c}0.61 \\
(0.11)\end{array}$ & $\begin{array}{c}2.54 \\
(0.24)\end{array}$ & $\begin{array}{c}3.94 \\
(0.21)\end{array}$ & $\mathrm{Nd}$ & - & - \\
\hline
\end{tabular}

Chemical data is recalculated to $100 \%$. Total Fe expressed as FeO. $\mathrm{H}_{2} \mathrm{O}$ by difference $(100-$ total oxides). Nd - not determined. Values in the brackets are standard deviation. Std. dev. - standard deviation. (A) - Present study, (B) - Dehn et al (1991) as reported by Lee et al (2004). (C) - South China Sea that includes 10 glass shards from ODP-1143 layer-2, 26 shards from core 17957 and 14 shards from core MD972142 (Lee et al 2004), (D) - average of 42 glass shards from different locations (Glass and Koeberl 2006). - : data not available, bdl - below detection limit.

layers $\mathrm{D}$ and $\mathrm{E}$ have distinct $\mathrm{Na}_{2} \mathrm{O} / \mathrm{K}_{2} \mathrm{O}$ ratios and $\mathrm{K}_{2} \mathrm{O}$ contents; with lower $\mathrm{Na}_{2} \mathrm{O} / \mathrm{K}_{2} \mathrm{O}(<0.8)$ and higher $\mathrm{K}_{2} \mathrm{O}(>4.5 \%)$ for layer $\mathrm{D}$ whereas higher $\mathrm{Na}_{2} \mathrm{O} / \mathrm{K}_{2} \mathrm{O}(>0.9)$ and lower $\mathrm{K}_{2} \mathrm{O}(<4.5 \%)$ in layer $\mathrm{E}$ (Lee et al 2004). The $\mathrm{Na}_{2} \mathrm{O} / \mathrm{K}_{2} \mathrm{O}$ ratio and $\mathrm{K}_{2} \mathrm{O}$ contents of the older ash layer in this study are consistent with those of OTT from Toba (Chesner 1988, 1998) and are similar to the SCS
(Lee et al 2004) and layer D from ODP site 758 (Dehn et al 1991). Furthermore, the $\mathrm{Sr}^{87} / \mathrm{Sr}^{86}$ ratio of glass shards from layer D (Lee et al 2004) is similar to that of the oldest Toba Tuff from Sumatra (Chesner 1988). Ash layer D from SCS is sandwiched between the Brunhes-Matuyama geomagnetic boundary (0.778 Ma) and Australasian microtektite $(0.77 \mathrm{Ma})$ suggesting that the layer D 

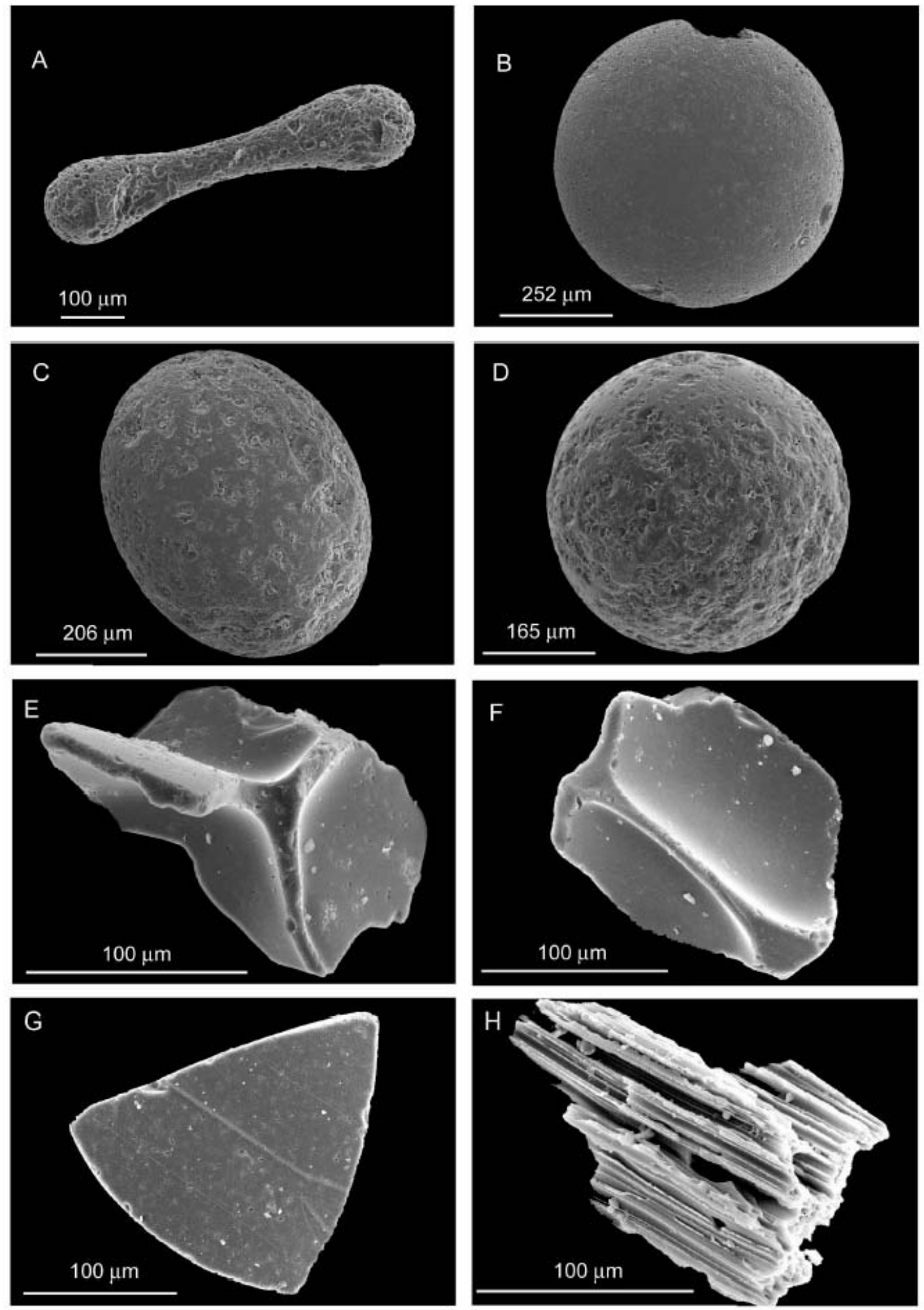

Plate 1. Morphology of microtektites: (A) dumbbell, (B) disc, (C) oval and (D) spherical shape. C and D contain microimpacts which are results of collision within ejecta at plume and are typically seen on several Australasian microtektites (Prasad et al 2003). These are from core AAS-V/GC-02 at a depth of 165-170 cm. Morphology of glass shards. (E) Bubble wall junction type where three glass bubbles were joined, $(\mathbf{F})$ bubble wall junction where two bubbles were joined, (G) flat shape and $\mathbf{( H )}$ pumice shard with striations. These are from core AAS-22/3 at $60-65 \mathrm{~cm}$ depth.

which is the primary OTT, cannot be older than $0.8 \mathrm{Ma}$ (Lee et al 2004). Therefore, in view of the similarity in chemical composition of the older
CIOB ash layer in this study and the SCS and layer D from ODP site 758, we suggest that they all are associated with the OTT eruption from Toba, 

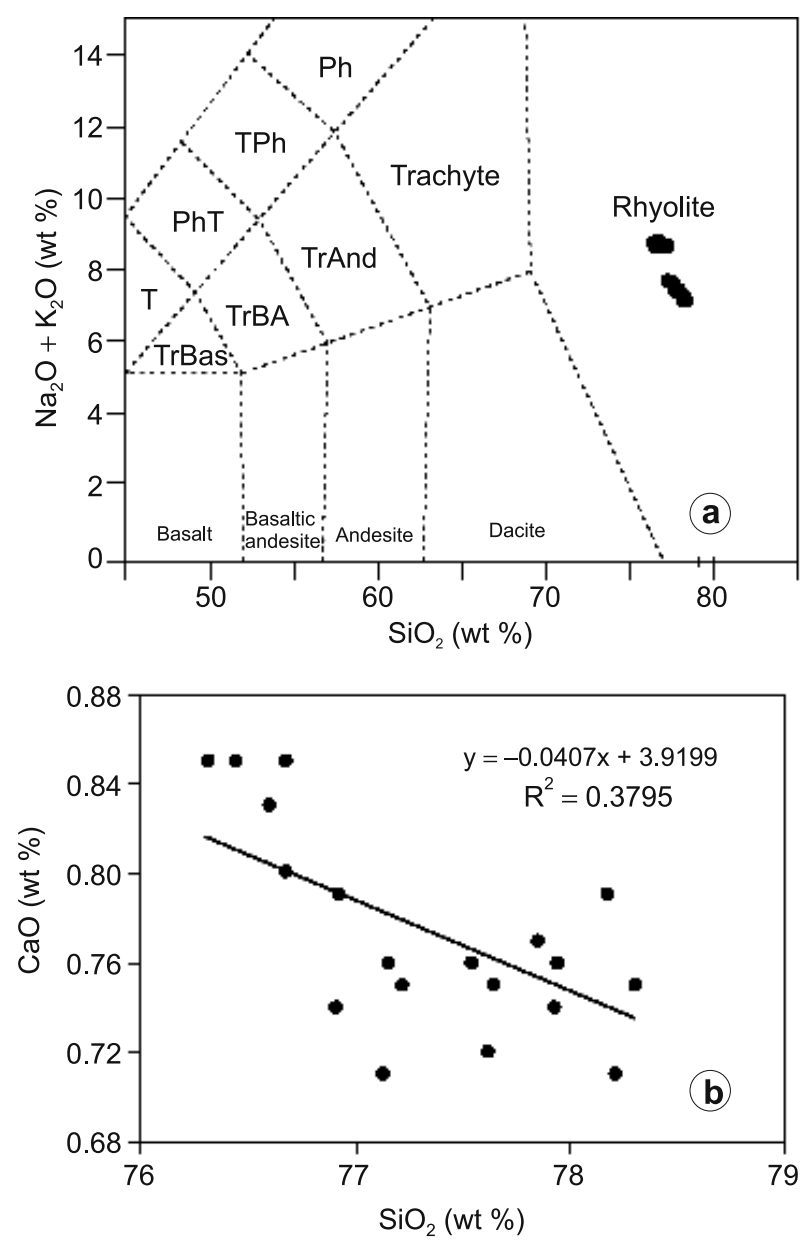

Figure 3. Geochemical classification diagrams of glass shards from CIOB.

Sumatra. This is further confirmed from the discrimination plots and ternary diagrams (figure 4). The chemistry thus suggests that the shards were deposited $\sim 3100 \mathrm{~km}$ to the southwest of Toba into the CIOB. Recently, Glass and Koeberl (2006) presented chemical data of glass shards which occur above the microtektite layer from the central Pacific and Indian Oceans. The chemistry of these shards does not match either layer D or layer $\mathrm{E}$ from ODP site 758, SCS and CIOB reported by Dehn et al (1991), Lee et al (2004), or in this study. Analysis by Glass and Koeberl (2006) are higher in $\mathrm{Al}_{2} \mathrm{O}_{3}, \mathrm{TiO}_{2}, \mathrm{MnO}$ and $\mathrm{MgO}$ and lower in concentration of $\mathrm{SiO}_{2}, \mathrm{FeO}, \mathrm{CaO}$ and $\mathrm{K}_{2} \mathrm{O}$ than layer $\mathrm{D}$ of the other studies. Since Glass and Koeberl (2006) studied the same cores and ash bearing strata as the other studies, this variation in chemistry could be due to the differences in the analytical procedures or type of instrument types. It is pertinent here, that both the groups of investigators (Lee et al 2004; Glass and Koeberl 2006) found ash layers just above or in association with Australasian microtektite, which is indicative of layer D. Therefore, we conclude that the second
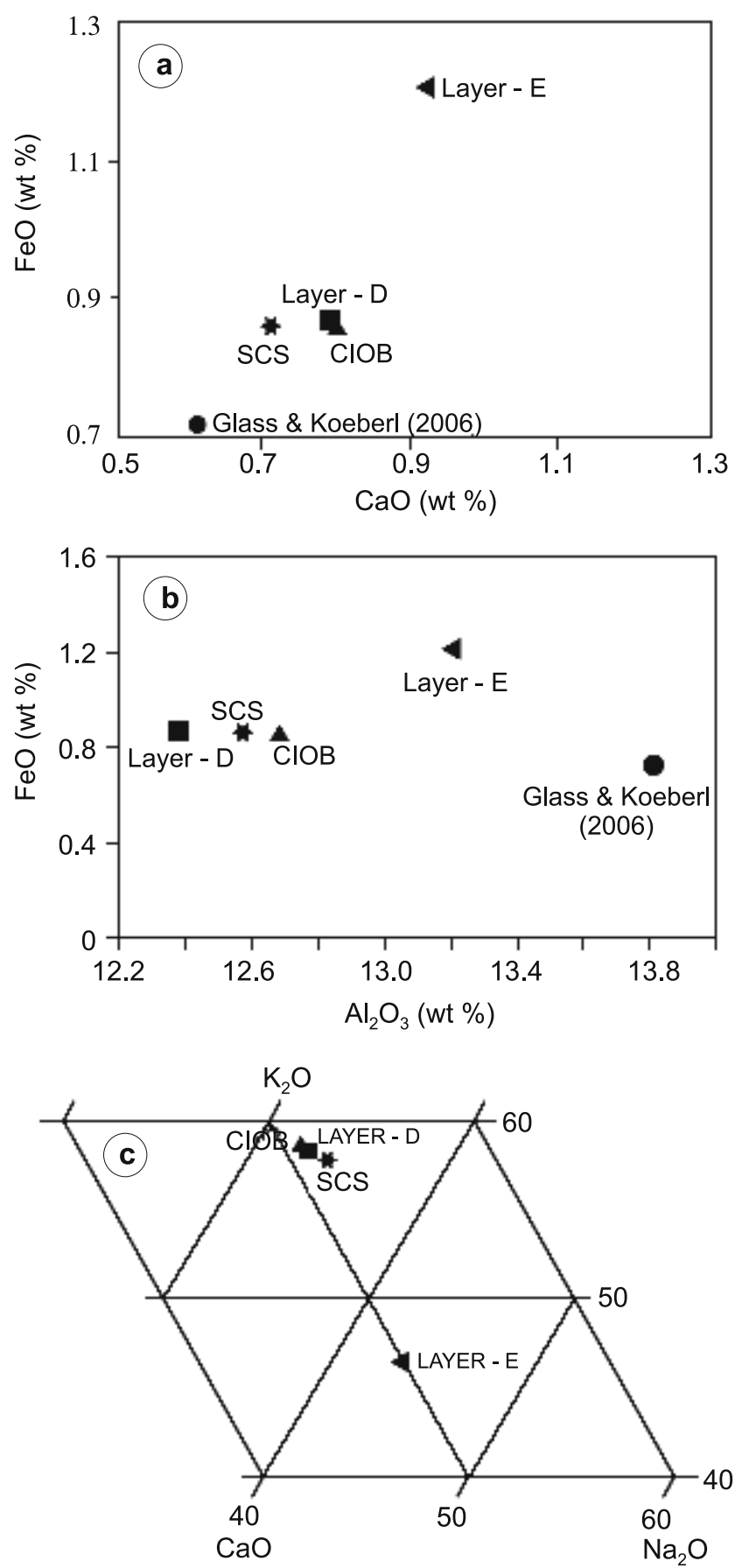

Figure 4. (a) Scatter plot of $\mathrm{FeO}(w t \%)$ vs. $\mathrm{CaO}$ (wt\%), (b) scatter plot of $\mathrm{FeO}$ (wt\%) vs. $\mathrm{Al}_{2} \mathrm{O}_{3}$ (wt\%) for different ash layers such as layers D and E from ODP site 758, CIOB, SCS and Glass and Koeberl (2006) data. (c) Ternary diagram of $\mathrm{K}_{2} \mathrm{O}-\mathrm{CaO}-\mathrm{Na}_{2} \mathrm{O}$ for the glass shards from layers $\mathrm{D}$ and E, CIOB and SCS.

ash layer in the CIOB is layer D and it is the OTT ashfall. Furthermore, we believe that layer E is not associated with the OTT.

Lee et al (2004) identified the distinct occurrence of layer $\mathrm{D}$ just above the microtektite layer at ODP site 758 as well as in sediment cores from the SCS. This has been possible because of 
the very high rates of sedimentation in the area allowing very high resolution stratigraphy. Glass and Koeberl (2006) reported ash overlapping, and some times just above the microtektite layer in the sediment cores from the central Pacific and the Indian Ocean. The overlapping of the ash layer and microtektite layers in CIOB (figure 2) could be due to low apparent sedimentation rates and probably due to relatively large sub-sampling intervals. Occurrence of layer D in the SCS and CIOB suggests that ash has traveled $\sim 2500 \mathrm{~km}$ northeast and $\sim 3100 \mathrm{~km}$ southwest from Toba caldera, respectively. This is suggestive of wind direction which could have been NE-SW during the OTT eruption time.

The presence of YTT and OTT in the sediment cores can be used to calculate the sediment accumulation rates. The sediment core AAS-V/GC-02 which is in the northern part of CIOB $\left(13^{\circ} \mathrm{S}\right)$ shows higher sedimentation rate of $5.1 \mathrm{~mm} / \mathrm{ka}$ in the top $38 \mathrm{~cm}$ depth which is above YTT. Sediments between YTT and OTT, i.e., between 38 and $167 \mathrm{~cm}$ depth correspond to 74 and $800 \mathrm{ka}$ respectively and yield a sedimentation rate of $1.63 \mathrm{~mm} / \mathrm{ka}$. The sedimentation rate $(5.1 \mathrm{~mm} / \mathrm{ka})$ above YTT is close to $4.5 \mathrm{~mm} / \mathrm{ka}$ derived by $\mathrm{U}-\mathrm{Th}$ technique in the same core (Pattan et al 2003). The southern sediment core AAS-22/3 $\left(17^{\circ} \mathrm{S}\right)$ shows comparatively slower sedimentation rates. Sediment above YTT yield a sedimentation rate of $1.7 \mathrm{~mm} / \mathrm{ka}$ and between YTT and OTT is only $0.7 \mathrm{~mm} / \mathrm{ka}$. It is clearly seen that sediments between YTT and OTT in both the sediment cores exhibit low sediment accumulation rates compared to sediments above YTT. Such a large variation in sedimentation rates may be due to changes in monsoonal intensities that in turn affected sediment supply to the Indian Ocean.

Glass and Koeberl (2006) proposed an area of $3.6 \times 10^{7} \mathrm{~km}^{2}$ covered by OTT ash based on its occurrence from the central Indian Ocean and central Pacific Ocean. Knight et al (1986), estimated a proximal OTT welded tuff DRE volume of $\sim 500 \mathrm{~km}^{3}$. Recently, Lee et al (2004) proposed a total OTT eruption volume of $\sim 800-1000 \mathrm{~km}^{3}$ DRE based on $500 \mathrm{~km}^{3}$ of welded tuff and $310-590 \mathrm{~km}^{3}$ of distal ash. The cores in the present study are located $\sim 3100 \mathrm{~km} \mathrm{SW}$ of Toba, Sumatra and are further from Toba than those in the SCS to the NE. Thus the area covered by OTT ash in the CIOB is more than that is reported in the central Pacific Ocean and the SCS. We therefore suggest an additional minimum volume of OTT ash beyond what Lee et al (2004) suggested. Our new OTT ash volume estimate of $1800 \mathrm{~km}^{3}$, obtained by multiplying the total area covered by ash $\left(3.6 \times 10^{6} \mathrm{~km}^{2}\right)$ by its minimum thickness $(5 \mathrm{~cm}$ from cores in this study). Combining the distal ash volume with the proximal welded OTT, the new total volume of the OTT eruption is $\sim 2300 \mathrm{~km}^{3}$. Such a volume qualifies the OTT eruption as a super-eruption of nearly comparable size to the infamous YTT eruption.

\section{Acknowledgements}

The authors are thankful to the Director, NIO, Goa for the facilities and the encouragement. We are grateful to Dr Phil Shane for chemical analysis of glass shards with EPMA on one sediment core and Prof. Steven Carey for the suggestions. Thanks are due to Dr C Koeberl and an anonymous reviewer for their constructive comments and suggestions which helped to improve the paper. We are particularly grateful to the anonymous reviewer for the detailed review. Mr. Vijay Khedekar is thanked for his help during SEM operation. This is NIO contribution no. 4734 .

\section{References}

Acharyya S K and Basu P K 1993 Toba ash on the Indian subcontinent and its implications for correlation of Late Pleistocene alluvium; Quat. Res. 40 10-19.

Bühring C and Sarnthein M 2000 Leg. 184 Shipboard Scientific Party, Toba ash layers in the South China Sea: Evidence of contrasting wind directions during eruption ca. 74 kyr; Geology 28 275-278.

Cassidy W A, Glass B P and Heezen B C 1969 Physical and chemical properties of Australasian microtektites; J. Geophys. Res. 74 1008-1025.

Chesner C A 1988 The Toba tuffs and caldera complex, Sumatra, Indonesia: Insights into magma bodies and eruptions; Thesis. Michigan Technol. University, 428 pp.

Chesner C A 1998 Petrogenesis of the Toba Tuffs, Sumatra; J. Petrol. 39(3) 397-438.

Chesner C A and Rose W I 1991 Stratigraphy of the Toba Tuffs and the evolution of the Toba caldera complex, Indonesia; Bull. Volcanol. 53 343-356.

Dehn J, Farrel J W and Schmincke H-U 1991 Neogene tephrochronology from site 758 on Ninetyeast Ridge: Indonesian arc volcanism of the past $5 \mathrm{Ma}$; Proc. ODP Sci. Results $121273-295$.

Diehl J F, Onstott T C, Chesner C A and Knight M D 1987 No short reversals of Brunhes age recorded in the Toba Tuffs, north Sumatra, Indonesia; Geophys. Res. Lett. 14 753-756.

Glass B P and Koeberl C 2006 Australasian microtektites and associated impact ejecta in the South China Sea and the middle Pleistocene supereruption of Toba; Meteoritics 83 Planetary Science 41(2) 305-326.

Glass B P, Huber H and Koeberl C 2004 Geochemistry of Cenozoic microtektites and clinopyroxene-bearing spherules; Geochim Cosmochim. Acta. 68 3971-4006.

Izett G A and Obradovich J D 1992 Laser-fusion ${ }^{40} \mathrm{Ar} /{ }^{39} \mathrm{Ar}$ ages of Australasian tektites (abstract); Proceedings 23rd Lunar and Planetary Science Conference, pp. 593-594.

Jarosewich E, Nelen J A and Norberg J A 1980 Reference samples for electron microprobe analysis; Geostandard Newsletter 4 43-47. 
Knight M D, Walker G P L, Ellwood B B and Diehl J F 1986 Stratigraphy, paleomagnetism and magnetic fabric of Toba tuffs: Constraints on the sources and eruptive styles; J. Geophys. Res. 91 10,355-10,382.

Korisettar R, Venkatesan T R, Misra S, Rajaguru S N, Somayajulu B L K, Tandon S K, Gogte V D, Ganjoo R K and Kale V S 1989 Discovery of a tephra bed in the Quaternary alluvial sediments of Pune district (Maharastra), Peninsular India; Curr. Sci. 58(10) $564-567$.

Kunz J, Bollinger K, Jessberger E K and Storzer D 1995 Ages of Australasian tektites (abstract); Proceedings 26th Lunar and Planetary Science Conference, pp. 809-810.

Lee M-Y, Chen C-H, Wei K-Y, Iizuka Y and Carey S 2004 First Toba supereruption revival; Geology 32(1) $61-64$.

Nambiar A R and Sukumaran P V 2002 Characterisation of Late Pleistocene Tephra in deep sea sediments of Arabian Sea; J. Geol. Soc. India 59 79-88.

Ninkovich D, Shackleton N J, Abdel-Monem A A, Obradovich J D and Izett G 1979 K-Ar age of the late Pleistocene eruption of Toba, north Sumatra; Nature $\mathbf{2 7 6}$ 574-577.

Nishimura S, Abe E, Yokoyama T, Wirasantosa S, Dharma A and Danau 1977 Toba - The outline of lake Toba, North Sumatra, Indonesia; Paleolimnology of Lake Biwa and the Japanese Pleistocene 5 313-332.

Pattan J N, Shane P and Banakar V K 1999 New occurrence of youngest Toba Tuff in abyssal sediments of the Central Indian Basin; Mar. Geol. 155 243-248.

Pattan J N, Masuzawa T, Borole D V, Parthiban G, Jauhari P and Yamamoto M 2003 Biological productivity, terrigenous influence and noncrustal elements supply to the Central Indian Ocean Basin: Paleoceanography during the past $\sim 1 \mathrm{Ma}$; J. Earth Syst. Sci. 114(1) 63-74.
Pattan J N, Shane P, Pearce N J G, Banakar V K and Parthiban G 2001 An occurrence of $\sim 74$ ka youngest Toba tephra from western continental margin of India; Curr. Sci. 80 1322-1326.

Prasad M S, Gupta S M and Kodagali V N 2003 Two layers of Australasian impact ejecta in the Indian Ocean?; Meteorit. Planet. Sci. 38 1373-1381.

Prasad M S, Mahale V P and Kodagali V N 2007 New sites of Australasian microtektites in the Central Indian Ocean: Implications for the location and size of source crater; J. Geophys. Res. 102 E06007, doi 10.1029/2006JE002857.

Rampino M R and Self S 1993 Climate-volcanism feedback and the Toba eruption of $\sim 74,000$ years ago; Quat. Res. $40269-280$.

Rose W I and Chesner C A 1987 Dispersal of ash in the great Toba eruption; Geology 15 913-917.

Schulz H, Kay-Christian Emeis, Erlenkeuser H, Von Rad U and Rolf C 2002 The Toba volcanic event and interstadial/stadial climates at the marine isotope stage 5 to 4 transition in the Northern Indian Ocean; Quat. Res. 57 $22-32$.

Shane P, Westgate J, Williams M and Korisettar R 1995 New geochemical evidence for the youngest Toba Tuff in India; Quat. Res. 44 200-204.

Song S-R, Chen C-H, Lee M-Y, Yangm T F, Iizuka Y and Wei K-Y 2000 Newly discovered eastern dispersal of the youngest Toba Tuff; Mar. Geol. 167 303-312.

Westgate J, Shane P, Pearce N, Perkins W, Korisettar R, Chesner C, Williams M and Acharyya S 1998 All Toba tephra occurrences across peninsular India belong to the 75,000 years B.P. eruption; Quat. Res. 50 107-112.

Yamei H, Potts R, Baoyin H, Zhengtang G, Dieno A, Wei W, Clark J, Guangmao X and Weiwen H 2000 MidPleistocene Acheulean-like stone technology of the Bose Basin, South China; Science 287 1622-1626. 